\title{
Changing structure of Employment in Europe: Polarization Issue
}

\section{Radek Náplava ${ }^{1}$}

\begin{abstract}
In recent years, labor markets have experienced a polarization phenomenon, with the rise of low-skill and high-skill workers, and a decline in the number of middleskill workers. The polarization of the labor market has been most often investigated in the US, UK, and some European countries. This paper shows the changes in the employment structure in all EU countries between 2008 and 2017. Attention is also paid to the Czech Republic and change during 1993 and 2017. The added value of the article lies in two factors. The first is the division of skills by industry in which the worker is located and not by occupational classification, the second is an explicit view of the Czech Republic. The results provide some evidence about the polarization of the labor market in twenty-one EU countries. Results imply polarization also in the Czech Republic during a longer period, because the number of high-skilled and low-skilled workers increased by 6.63 p. p. and by 1.16 p. p. respectively, at the expense of middle-skilled workers.
\end{abstract}

Keywords: polarization, labor market, employment, skills

JEL Classification: J210, J230

Received: 21 December 2018 / Accepted: 5 November 2019 / Sent for Publication: 5 December 2019

\section{Introduction}

The constantly changing structure of consumer demand is a source of dynamics of the economic system, reflecting these changing tendencies, through changes in the employment structure. Earlier beliefs that the demand for workers grows directly in line with their skill levels have proven to be wrong in some countries during last decades because job polarization has appeared (Autor, Levy, and Murnane, 2003; Goos and Manning, 2007; Goos, Manning, and Salomons, 2009). For a long time, it was believed that the demand for workers grows in proportion to their skills ${ }^{2}$ : jobs requiring higherskill levels are demanded more, and lower-skill levels are demanded less. This phenom-

\footnotetext{
${ }^{1}$ Mendel University, Faculty of Business and Economics, Department of Economics, Zemědělská 1, 61300 Brno, Czech Republic. Email: xnaplava@mendelu.cz

${ }^{2}$ Acemoglu (1998), Autor and Katz (1999), Berman, Bound, and Machin (1998) and others.
}

(c) 2019 by the authors; licensee Review of Economic Perspectives / Národohospodárský obzor, Masaryk University, Faculty of Economics and Administration, Brno, Czech Republic. This article is an open access article distributed under the terms and conditions of the Creative Commons Attribution 3.0 license, Attribution - Non Commercial - No Derivatives. 
enon is referred to in the literature as the skill-biased technological change hypothesis ("SBTC"). ${ }^{3}$ Higher levels of technology engagement in production also result in a higher demand for relatively skilled labor that would operate the new technology. The SBTC hypothesis has long been used to explain the situation on the labor market, but it cannot explain the recent polarization phenomenon.

Job polarization means employment growth in high-skill and low-skill occupations, while the employment of middle-skill occupations declines (Autor, Katz, and Kearney, 2006). Goos, Manning, and Salomons (2014) showed some examples of occupations divided by the required skills: high-skill jobs are those of managers, scientists and professionals; machine operators and assemblers, office clerks and drivers are middleskilled occupations, and, finally, low-skilled are workers in construction, mining, manufacturing, and sales and service elementary occupations. While the SBTC hypothesis does not explain polarization in the labor market, its modified version RBTC (routinebiased technological change) is an explanation widely accepted among economists (Autor, Levy, and Murnane, 2003; Goos and Manning, 2007). The RBTC hypothesis was formulated by Autor, Levy, and Murnane (2003). They divide occupations into routine, non-routine, manual and cognitive. If the routine profession is well defined, it is also possible to replace a middle-skilled worker with a less qualified worker (which is usually done as part of offshoring). The routine of the profession (and related offshoring) is, therefore, an explanatory factor for the emergence of the labor market polarization (Autor, Levy, and Murnane, 2003; Goos, Manning, and Salomons, 2009).

The polarization of the labor market was most often investigated in the US, UK, and some other European countries. The results have shown that polarization has occurred in these countries since the turn of the 1980s. Bárány and Siegel (2018a) show that this has happened in the USA since the 1950s, however, its emergence depends on the specific variables measured or methods used. ${ }^{4}$

This issue has only gained attention in the last 10-15 years. Given the availability and quality of the data, the US labor market was the first examined. Later, attention focused on the UK and some European countries. Autor and Dorn (2013) and Bárány and Siegel (2018a) investigated the US labor market; Goos and Manning (2007) dealt with Great Britain; Goos, Manning, and Salomons (2009, 2014), Milet and Toubal (2014), PertoldGebicka (2014) addressed selected European countries. In all these cases, labor market polarization was proven. Although there are contributions that do not directly prove polarization, they admit changes in the employment structure that these trends may show in the future (e.g., Fernández-Macías, 2012).

The main purpose of this article is to determine whether there has been job polarization in EU countries and in the Czech Republic as a representant of CEE countries. The first

\footnotetext{
${ }^{3}$ About SBTC see primarily Krueger (1993) and for critical discussion Card and DiNardo (2002) and Manning (2004).

${ }^{4}$ For example: papers considering technological changes as a explanatory power for job polarization show start of polarization from the 1980s onwards, while papers considering offshoring or structural changes see the start of polarization earlier (see Bárány and Siegel, 2018a).
} 
contribution of this paper is the use of an alternative approach to determining skills. Skills are determined not by occupational classification (usually ISCO), but by industry in which the worker is located. The first part of the results section deals with the EU and the changes in the structure of employment in 2008-2017, the second part deals with the Czech Republic and the years between 1993 and 2017. Relative changes in employment are used to identify possible job polarization. The results show that the industries classified as high- and low-skilled have seen an increase in the number of laborers at the expense of middle-skilled laborers in $21 \mathrm{EU}$ countries. In the remaining seven countries, there seems to be no job polarization. The second contribution of this paper is special focus on the Czech Republic which is within a deeper perspective neglected in thematic literature, same as other CEE countries. The results imply polarization of the labor market during 1993-2017. Laborers from middle-skilled industries relocate rather to the high-skilled industries.

The paper is structured as follows. The introduction explains the motivation, context, and main objective of the paper. The next section mainly describes how the industries are divided into high, middle and low-skilled. Further, the results of descriptive analysis are presented, which point to the polarization of the labor market in the EU during 2008-2017 and in the Czech Republic in 1993-2017. The last section concludes the findings and discusses results.

\section{Methodology and Data}

This contribution takes data from two sources: there are Eurostat for the EU countries and the Czech Statistical Office for the Czech Republic. Industries are classified by the NACE Rev. 2 classification of economic activities. The division of the industries is based on the contribution of Amoroso and Moncada-Paternò-Castello (2018). They use the ISCO classification to divide employee skills. Based on the proportions of high-, middle- and low-skilled employees in industries, these industries are divided into high, middle, and low-skilled industries. ${ }^{5}$ For illustration, when we take the "P" sector (Education), we will say that high-skill laborers work in this sector. Table 1 below gives an overview of the industries and their distribution based on the skill level.

Usually, the ISCO occupational classification is used to determine the level of skills, where jobs that have similar skills requirements are pooled. Occupations are then most often classified on the basis of wages (Goos, Manning, and Salomons, 2009; 2014; Manning, 2004), as higher wages should correspond to higher skill levels (Autor, 2010). Furthermore, skill levels are determined on the basis of the education of individual workers (Acemoglu, 1998; Michaels, Natraj, and Van Reenen, 2014). However, these approaches may also have their drawbacks. The wage of a single occupation may have a wide dispersion within the region (Goos and Manning, 2007). Similarly, a high level of education does not necessarily mean that a worker performs a job that corresponds to

\footnotetext{
${ }^{5}$ An attempt to divide the industries can be also found in Bárány and Siegel (2018a,b). These authors classify industries according to the share of manual (low-skilled non-routine) workers, routine workers, and abstract (skilled non-routine) workers.
} 
his level of knowledge (Erdogan et al., 2011; McGuinness, 2006; and other papers dealing with overqualification and overeducation).

Table 1. Division of industry by NACE Rev. 2

\begin{tabular}{ccc} 
High-skills & Middle-skills & Low-skills \\
\hline J & A & E \\
K & B & I \\
L & C & N \\
M & D & S \\
O & F & \\
P & G & \\
Q & H
\end{tabular}

Source: Based on Amoroso and Moncada-Paternò-Castello (2018).

Note: Amoroso and Moncada-Paternò-Castello (2018) do not include the " $R$ " industry (Arts, Entertainment and Recreation), so this industry is omitted.

$A=$ Agriculture, Forestry and Fishing; $B=$ Mining and quarrying; $C=$ Manufacturing; $D=$ Electricity \& gas; $E=$ Water and sewerage; $F=$ Construction; $G=$ Wholesale and retail trade; $H=$ Transport and Storage; $I=$ Hotels \& catering; $J=$ Information and Communication; $K=$ Financial intermediation; $L=$ Real Estate; $M=$ Professional, Scientific and Technical activities; $N=$ Administrative and Support Service activities; $O=$ Public administration and defence; compulsory social security; $P=$ Education; $Q=$ Health and social work; $R=$ Arts, Entertainment and Recreation; $S=$ Other service activities

The selected approach requires great simplification provided a homogeneous employment structure within the industry. Nevertheless, it appears that there is rellocation of labor from the middle-skilled industries to the high- and low-skilled industries. As pointed Bárány and Siegel (2018b), job polarization not only across occupations but also by industries shows the depth of structural change.

First, EU countries are investigated between 2008 and 2017. In 2008, the methodology for classifying NACE activities changed, so it only covers the dataset for the last ten years. In addition, attention focuses on the Czech Republic and the years between 1993 and 2017. The main observed indicator is the relative change in employment because the use of relative changes has better explanatory power than absolute changes.

\section{Results}

\section{Polarization of labor market within EU countries}

The first figure shows the relative change in employment in the EU between year 2017 and the year 2008, distributed by the skill level. It is the sum of all countries and industries within them. That figure provides some evidence about polarization within EU countries. Polarization demonstrates an increase in the number of employees in highskill industries ( 2 p. p.), and low-skill industries (more than 1.3 p. p.), while in the middle-skill industries there is a pronounced decline in the number of employees (about 3.7 p. p.). A more detailed view of individual countries provides Table 2 below. 
Figure 1. Relative change in employment in the EU between 2017 and 2008 within industries.

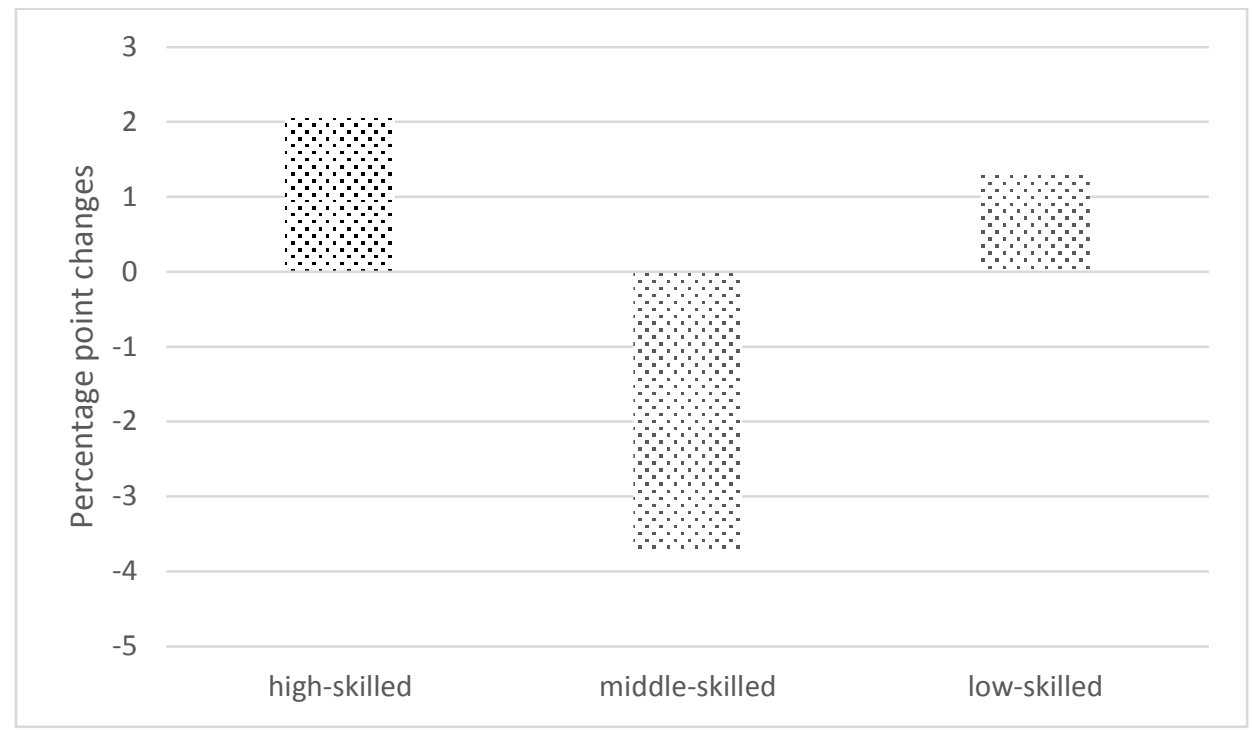

Source: author's own calculation, based on the Eurostat.

Table 2. Relative change in employment in the EU between 2017 and 2008

\begin{tabular}{l|ccc|l|ccc} 
& \multicolumn{3}{|c|}{$\begin{array}{c}\text { Percentage point changes } \\
(2008-2017)\end{array}$} & & \multicolumn{3}{c}{$\begin{array}{c}\text { Percentage point changes } \\
(2008-2017)\end{array}$} \\
\hline Country & HS & MS & LS & Country & HS & MS & LS \\
\hline Austria & 3.56 & -3.91 & 0.49 & Italy & -0.64 & -3.84 & 2.43 \\
Belgium & 2.45 & -4.55 & 2.23 & Latvia & 6.25 & -6.78 & 0.50 \\
Bulgaria & 1.54 & -4.05 & 2.11 & Lithuania & 2.37 & -4.60 & 1.84 \\
Croatia & 4.71 & -7.65 & 2.58 & Luxembourg & -4.17 & -10.38 & -0.48 \\
Cyprus & 1.60 & -3.86 & 3.66 & Malta & 3.63 & -5.06 & -0.33 \\
Czechia & 3.25 & -2.73 & -0.62 & Netherlands & -3.84 & -2.85 & 1.56 \\
Denmark & 0.94 & -4.07 & 2.05 & Poland & 0.73 & -1.76 & 0.57 \\
Estonia & 4.90 & -6.48 & 1.42 & Portugal & 4.57 & -5.93 & 1.76 \\
Finland & 3.82 & -4.65 & 0.52 & Romania & 0.80 & -3.67 & 2.46 \\
France & 2.51 & -3.01 & 1.00 & Slovakia & 4.30 & -4.47 & -0.58 \\
Germany & 1.78 & -1.47 & -0.21 & Slovenia & 3.74 & -4.47 & 0.83 \\
Greece & 2.84 & -5.78 & 4.03 & Spain & 4.41 & -6.96 & 2.54 \\
Hungary & 1.62 & -2.58 & 0.80 & Sweden & 2.92 & -4.24 & 1.05 \\
Ireland & 3.56 & -4.84 & 1.42 & U. Kingdom & 2.82 & -5.61 & 2.47 \\
\hline
\end{tabular}

Source: author's own calculation, based on the Eurostat.

Note: $H S=$ high-skill industries; $M S=$ middle-skill industries; $L S=$ low-skill industries. 
In the countries in bold, the polarization of the labor market took place in the period 2008-2017: an increase in the number of high- and low-skill laborers and decrease in middle-skill laborers. Thus, the phenomenon of polarization can be seen in twenty-one countries out of the European twenty-eight. An increasing number of high-skilled laborers is a trend in all countries except Italy, Luxembourg and the Netherlands. Trends in middle-skill workers are the opposite - a decline is present in all countries. This is consistent with Goos, Manning, and Salomons (2009; 2014). The increase in the number of low-skilled laborers, a phenomenon typical of polarization, and the factor that makes polarization a potential problem is broken only in the cases of the Czech Republic, Germany, Luxembourg, Malta, and Slovakia. In these countries, with the exception of Luxembourg, workers are being relocated towards higher-skilled industries, which is consistent with SBTC hypothesis presented in the Introduction. For similar results of low-skilled laborers see Fernández-Macías (2012), and Oesch and Rodríguez Menés (2010).

\section{Polarization of the labor market in the Czech Republic}

Figure 2 shows the aggregate relative change in employment in the Czech Republic between the year 2017 and the year 1993, distributed in industries by skills. Here too, as in the case of aggregated results for the EU countries, we can see a typical picture corresponding to the polarization of the labor market. Unlike the EU countries, however, this is a relative change during twenty-five years. The results show that the number of highly qualified laborers in high-skill industries increased by more than $6 \mathrm{p}$. p. and lowskilled laborers in low-skill industries by about 1 p. p., while the number of middleskilled laborers decreased by approximately 9 p. p.

Figure 2. Relative change in employment in the Czech Republic between 2017 and 1993 within industries.

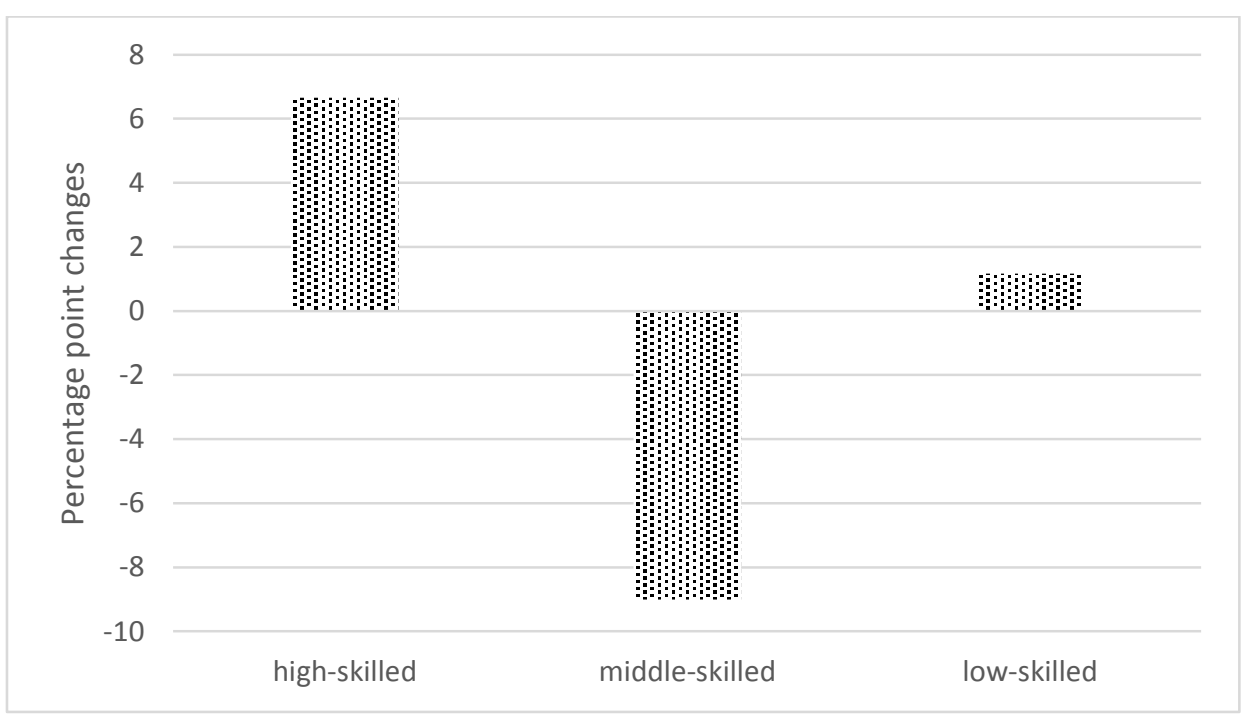

Source: author's own calculation; based on the Czech Statistical Office. 
The extension of the time series by 15 years shows that the polarization of the labor market (shown in Figure 2) has moderated during 2008-2017 (Table 2, which does not show polarization). Extending or shifting the time series can produce different results; see the results of Goos, Manning, and Salomons (2009) versus Goos, Manning, and Salomons (2014) for Austria, Denmark, France, and Italy, where polarization does not take effect until the time series is extended.

Relative changes in employment in each industry are presented in Table 3 below.

Table 3. Relative change in employment in the Czech Republic between 2017 and 1993 at the industrial level

\begin{tabular}{lcc|lcc} 
Industry & $\begin{array}{c}\text { Change in } \\
\text { p.p. }\end{array}$ & $\begin{array}{c}\text { Industry } \\
\text { status }\end{array}$ & Industry & $\begin{array}{c}\text { Change in } \\
\text { p.p. }\end{array}$ & $\begin{array}{c}\text { Industry } \\
\text { status }\end{array}$ \\
\hline A & $-4,55$ & Middle-skill & J & 0,94 & High-skill \\
B & $-1,92$ & Middle-skill & K & 0,79 & High-skill \\
C & $-0,97$ & Middle-skill & L & 0,29 & High-skill \\
D & $-0,64$ & Middle-skill & M & 2,59 & High-skill \\
E & 0,30 & Low-skill & N & 0,75 & Low-skill \\
F & $-1,55$ & Middle-skill & O & 0,40 & High-skill \\
G & 1,28 & Middle-skill & P & 0,11 & High-skill \\
H & $-0,66$ & Middle-skill & Q & 1,51 & High-skill \\
I & 0,25 & Low-skill & S & $-0,14$ & Low-skill \\
\hline
\end{tabular}

Source: author's own calculation; based on the Czech Statistical Office.

Note: The first line contains industries according to Nace Rev. 2, the second one contains relative changes in employment between 2017 and 1993, and the third line shows the industry status.

The largest decline can be seen in 'A' (agriculture, forestry, and fishing) and 'B' (mining and quarrying); both sectors have the largest share of middle-skilled laborers. The largest increase, on the other hand, is in the "M" sector (professional, scientific and technical activities), the sector with the highest share of highly qualified laborers. The precondition for polarization is only broken in the case of the "G" (wholesale and retail trade) industry - the number of middle-skilled laborers increased by $2.59 \%$-, and "S" industries (other service activities), where the number of low-skilled laborers decreased by $0.14 \%$. However, aggregate results captured in Figure 2 correspond to the presence of polarization.

\section{Socio-economic impacts of job polarization}

The growing number of the most qualified (high-skilled) and the least qualified (lowskilled) laborers at the expense of the middle-class (middle-skilled) laborers is a reality that carries a potential threat that is not explicitly mentioned in a relatively large part of the thematic literature. Many articles only deal with the descriptive aspect of the issue or the context that has caused polarization, but they do not address the reasons why polarization is problematic and what socio-economic implications it carries - see contri- 
butions by Fernández-Macías (2012), Goos and Manning (2007) Milet and Toubal (2014), Bárány and Siegel (2018a) and others. One of them is mainly the deepening of income inequality (Autor, 2010), which may result at the end of the middle class. The decline in the demand for middle-skilled jobs reduces the relative wage of this group of workers. Table 4 below shows the Gini coefficient value from 2008 and 2017.

Table 4. Gini coefficient of equivalised disposable income in EU countries

\begin{tabular}{l|ccc|l|ccc} 
Country & 2008 & 2017 & Polarization? & Country & 2008 & 2017 & Polarization? \\
\hline Austria & 27.7 & 27.9 & YES & Italy & 31.2 & 32.7 & NO \\
Belgium & 27.5 & 26.0 & YES & Latvia & 37.5 & 34.5 & YES \\
Bulgaria & 35.9 & 40.2 & YES & Lithuania & 34.5 & 37.6 & YES \\
Croatia & n.a. & 29.9 & YES & Luxembourg & 27.7 & 30.9 & NO \\
Cyprus & 29.0 & 30.8 & YES & Malta & 28.1 & 28.2 & NO \\
Czechia & 24.7 & 24.5 & NO & Netherlands & 27.6 & 27.1 & NO \\
Denmark & 25.1 & 27.6 & YES & Poland & 32.0 & 29.2 & YES \\
Estonia & 30.9 & 31.6 & YES & Portugal & 35.8 & 33.5 & YES \\
Finland & 26.3 & 25.3 & YES & Romania & 35.9 & 33.5 & YES \\
France & 29.8 & 29.3 & YES & Slovakia & 23.7 & 23.2 & NO \\
Germany & 30.2 & 29.1 & NO & Slovenia & 23.4 & 23.7 & YES \\
Greece & 33.4 & 33.4 & YES & Spain & 32.4 & 34.1 & YES \\
Hungary & 25.2 & 28.1 & YES & Sweden & 25.1 & 28.0 & YES \\
Ireland & 29.9 & 30.6 & YES & U. Kingdom & 33.9 & 33.1 & YES \\
\hline Source: Eun & \multicolumn{7}{|l}{}
\end{tabular}

Source: Eurostat.

Note: A higher number means higher income inequality. Column "Polarization?" is based on the results of Table 2.

According to the above, income inequality should increase in countries where polarization is taking place. Polarization and income inequality increased simultaneously in 14 countries. There was polarization in one country (Greece), but the Gini coefficient did not change. Polarization occurred in six countries, but there was no increase in income inequality. In addition, according to Acemoglu and Autor (2011), wages are rising faster in high-skill jobs than low-skill jobs (which, however, reflects the higher demand for the most qualified positions). Table 5 below shows the income quintile share ratio of $\mathrm{S} 80 / \mathrm{S} 20$.

Of the 21 countries where polarization was found, the proportion of the income quintile of S80/S20 increased in 12 of them. In one country (Finland) the ratio remained unchanged, while in the remaining eight, the ratio decreased. For valid conclusions in this matter, a longer time series would be needed, as in Autor (2010) and Acemoglu and Autor (2011). However, these conclusions may still contribute to the discussion of the socio-economic implications of these (relatively new) labor market trends. 
Table 5. S80/S20 income quintile share ratio in EU countries

\begin{tabular}{l|ccc|l|ccc} 
Country & 2008 & 2017 & Polarization? & Country & 2008 & 2017 & Polarization? \\
\hline Austria & 4.2 & 4.4 & YES & Italy & 5.4 & 6.3 & NO \\
Belgium & 4.1 & 4.0 & YES & Latvia & 7.1 & 6.3 & YES \\
Bulgaria & 6.8 & 9.0 & YES & Lithuania & 6.4 & 7.8 & YES \\
Croatia & n.a. & 5.0 & YES & Luxembourg & 4.3 & 5.1 & NO \\
Cyprus & 4.0 & 4.5 & YES & Malta & 4.3 & 4.2 & NO \\
Czechia & 3.6 & 3.5 & NO & Netherlands & 4.1 & 4.2 & NO \\
Denmark & 3.6 & 4.4 & YES & Poland & 5.4 & 4.8 & YES \\
Estonia & 5.0 & 5.5 & YES & Portugal & 6.2 & 5.9 & YES \\
Finland & 3.7 & 3.6 & YES & Romania & 7.4 & 7.0 & YES \\
France & 4.4 & 4.4 & YES & Slovakia & 3.5 & 3.7 & NO \\
Germany & 4.9 & 4.6 & NO & Slovenia & 3.3 & 3.4 & YES \\
Greece & 6.2 & 6.7 & YES & Spain & 5.6 & 7.2 & YES \\
Hungary & 3.8 & 4.4 & YES & Sweden & 3.7 & 4.4 & YES \\
Ireland & 4.5 & 4.8 & YES & U. Kingdom & 5.7 & 5.6 & YES \\
\hline
\end{tabular}

Source: Eurostat.

Note: Column "Polarization?" is based on the results of Table 2.

\section{Discussion and Conclusions}

This paper contributes to the debate on the structural changes in the EU employment. Current trends include the polarization of the labor market, which is documented in a number of countries. The results of this contribution provide some evidence of this phenomenon on a sample of EU countries between the years 2008 and 2017 and for the Czech Republic between 1993 and 2017. The evaluation criteria are relative changes in employment across industries. The division of the industry is based on the contribution of Amoroso and Moncada-Paternò-Castello (2018), who classify the industry on the basis of the composition of workers working within them. This approach is alternative to other articles because the skill level distribution is not based on occupational classification (which is usually ISCO classification).

Relative changes in employment show that during 2008-2017, there has been a rellocation of labor force from industries that we can classify as middle-skilled to industries that we can classify as high-skilled and low-skilled. The decline of laborers in the middle-skilled industries was a trend in all EU countries. The average decline was 4.6 p. p. and was compensated by growth in the number of laborers in the high- and middleskilled industries. The longer time series (25 years) for the Czech Republic also shows a polarized labor market - the decline in middle-skilled laborers (by 9 p. p.) was compensated primarily by the increase in the number of high-skilled laborers, while the proportion of low-skilled laborers also increased, but less (by 1.16 p. p.).

Although this paper is descriptive and uses an alternative approach, the results support the hypothesis that there are changes in the labor market that have not been predicted by 
SBTC hypothesis. There are a lot of articles that confirm job polarization: the most influential contributions are especially from Autor, Levy, and Murnane (2003), Goos and Manning (2007), and Goos, Manning, and Salomons (2009). But, there is an opposition that stresses skill-upgrading which is consistent with SBTC hypothesis. Skillupgrading means that high-skilled occupations expanse at the expense of low-skilled occupations (Oesch and Rodríguez Menés, 2010). Especially Fernández-Macías (2012) provides some evidence about conflict between polarization tendencies and skillupgrading.

Division of skills by industry in which the worker is located, assumes a homogeneous structure of occupations within each sector. This is a major simplification of the situation because each sector is made up of many kinds of diverse occupations. This simplification may be the weakness of this contribution, but it also shows the current trends in labor markets that should not be ignored.

Acknowledgements: I am very grateful for valuable comments from my colleagues Jitka Doležalová and Petr Rozmahel.

Funding: The contribution is a result of the research project IGA MENDELU PEF_DP_2018021.

Disclosure statement: The author reported no potential conflict of interest.

\section{References}

ACEMOGLU, D. (1998). Why do new technologies complement skills? Directed technical change and wage inequality. The Quarterly Journal of Economics, 113(4), 10551089. DOI: $\underline{10.1162 / 003355398555838}$

ACEMOGLU, D.; AUTOR, D. H. (2011). Skills, tasks and technologies: Implications for employment and earnings. In: Handbook of labor economics. Elsevier. p. 10431171. DOI: 10.1016/S0169-7218(11)02410-5.

AMOROSO, S.; MONCADA-PATERNÒ-CASTELLO, P. (2018). Inward greenfield FDI and patterns of job polarization. Sustainability, 10.4: 1219. DOI: $\underline{10.3390 / \mathrm{su} 10041219}$

AUTOR, D. H. (2010). The polarization of job opportunities in the US labor market: Implications for employment and earnings. Center for American Progress and The Hamilton Project, 6.

AUTOR, D. H.; DORN, D. (2013). The growth of low-skill service jobs and the polarization of the US labor market. American Economic Review, 103.5: 1553-97. DOI: $\underline{10.1257 / \text { aer.103.5.1553 }}$

AUTOR, D. H.; KATZ, L. F. (1999). Changes in the wage structure and earnings inequality. In Handbook of labor economics. Elsevier. p. 1463-1555. DOI: 10.1016/S15734463(99)03007-2

AUTOR, D., H.; KATZ, L. F.; KEARNEY, M. S. (2006). The polarization of the US labor market. American economic review, 96.2: 189-194. DOI: $\underline{10.1257 / 000282806777212620}$ 
AUTOR, D. H.; LEVY, F.; MURNANE, R. J. (2003). The skill content of recent technological change: An empirical exploration. The Quarterly journal of economics, 118.4: 1279-1333. DOI: 10.1162/003355303322552801

BÁRÁNY, Z. L.; SIEGEL, C. (2018a). Job polarization and structural change. American Economic Journal: Macroeconomics, 10.1: 57-89. DOI: 10.1257/mac.20150258

BÁRÁNY, Z. L.; SIEGEL, C. (2018b). Biased technological change and employment reallocation. School of Economics Discussion Papers.

BERMAN, E.; BOUND, J.; MACHIN, S. (1998). Implications of skill-biased technological change: international evidence. The quarterly journal of economics, 113(4), 1245-1279. DOI: $10.1162 / 003355398555892$

CARD, D.; DINARDO, J. E. (2002). Skill-biased technological change and rising wage inequality: Some problems and puzzles. Journal of labor economics, 20.4: 733-783. DOI: $\underline{10.1086 / 342055}$

ERDOGAN, B., BAUER, T. N., PEIRÓ, J. M.,TRUXILLO, D. M. (2011). Overqualified employees: Making the best of a potentially bad situation for individuals and organizations. Industrial and Organizational Psychology, 4(2), 215-232. DOI: 10.1111/j.1754-9434.2011.01330.x

FERNANDEZ-MACIAS, E. (2012). Job polarization in Europe? Changes in the employment structure and job quality, 1995-2007. Work and Occupations, 39.2: 157-182. DOI: $10.1177 / 0730888411427078$

GOOS, M.; MANNING, A. (2007). Lousy and lovely jobs: The rising polarization of work in Britain. The review of economics and statistics, 89.1: 118-133. DOI: $\underline{10.1162 / \text { rest.89.1.118 }}$

GOOS, M.; MANNING, A.; SALOMONS, A. (2009). Job polarization in Europe. American economic review, 99.2: 58-63. DOI: 10.1257/aer.99.2.58

GOOS, M.; MANNING, A.; SALOMONS, A. (2014). Explaining job polarization: Routine-biased technological change and offshoring. American Economic Review, 104.8: 2509-26. DOI: 10.1257/aer.104.8.2509

KRUEGER, A. B. (1993). How computers have changed the wage structure: evidence from microdata, 1984-1989. The Quarterly Journal of Economics, 108.1: 33-60. DOI: $\underline{10.2307 / 2118494}$

MANNING, A. (2004). We can work it out: the impact of technological change on the demand for low-skill workers. Scottish Journal of Political Economy, 51.5: 581-608. DOI: $\underline{10.1111 / \mathrm{j} .0036-9292.2004 .00322 . \mathrm{x}}$

MCGUINNESS, S. (2006). Overeducation in the labour market. Journal of economic surveys, 20(3), 387-418. DOI: 10.1111/j.0950-0804.2006.00284.X

MICHAELS, G.; NATRAJ, A.; VAN REENEN, J. (2014). Has ICT polarized skill demand? Evidence from eleven countries over twenty-five years. Review of Economics and Statistics, 96.1: 60-77. DOI: 10.1162/REST_a_00366

MILET, E.; TOUBAL, F. (2014). Services Imports and Job Polarization. 
OESCH, D.; RODRÍGUEZ MENÉS, J. (2010). Upgrading or polarization? Occupational change in Britain, Germany, Spain and Switzerland, 1990-2008. Socio-Economic Review, 9.3: 503-531. DOI: 10.1093/ser/mwq029

PERTOLD-GEBICKA, B. (2014). Job Market Polarization and Employment Protection in Europe. Economic Studies \& Analyses/Acta VSFS, 8.2. 